\title{
PENERAPAN SOCIALPRENEURSHIP DALAM PENGEMBANGAN KUALITAS POTENSI HIDUP PADA ANAK JALANAN DI JAKARTA TIMUR
}

\section{THE APPLICATION OF SOCIALPRENEURSHIP IN DEVELOPMENT OF QUALITY OF LIVING POTENTIALS IN STREET CHILDREN IN EAST JAKARTA}

\author{
P Ariwibowo $^{1 a}$, Priyono ${ }^{1}$, N Yulanda ${ }^{1}$ \\ ${ }^{1}$ Program Studi Pendidikan Ekonomi, Fakultas Pengetahuan dan Pendidikan Sosial, Universitas \\ Indraprasta PGRI Jakarta, Jl. Nangka Raya No 58 C, Rt 5/ Rw 5, Tanjung Barat, Jagakarsa, Kota Jakarta \\ Selatan, Daerah Khusus IbuKota Jakarta 12530 Indonesia. \\ a Korespondensi: Prasetio Ariwibowo, E-mail: Prasetio.ariwibowo@yahoo.com \\ (Diterima: 19-02-2019; Ditelaah: 12-02-2019; Disetujui: 01-04-2019)
}

\begin{abstract}
The purpose of implementing community service for the community, especially street children under the auspices of the ERBE foundation, Kebon Kopi East Jakarta, is as follows: 1) Reducing the number of underage children empowered by parents as a source of income . 2) Expanding business opportunities that are relatively limited. 3) Growing knowledge gained by the community regarding entrepreneurship, especially good and correct sociopreneurship, and 4) optimizing productive economic business and expanding market access for people who already have businesses. The implementation of this activity involved 2 partners (targets) of the community, namely the East Jakarta City Social Service and ERBE Foundation, Kebon Kopi, East Jakarta. This activity is held on 20-21 November 2018. This activity on the first day starts at 09.00 - 12.00 WIB at ERBE Kebon Kopi Street Children Foundation - East Jakarta and the second day at ERBE Kebon Kopi Street Children Foundation - East Jakarta at 14.00 - 17.00 WIB. The total number of participants who participated was 50 people. The results of the implementation of Community Service activities in the form of sub-activities "The Innovative Product of Patchwork" and entrepreneurial character development through sociopreneur concept can be considered successful or have been successfully implemented with the percentage of planning, the results are $91.66 \%$; $95 \%$, and $87.5 \%$ in the very good category.
\end{abstract}

Keywords : ERBE Foundation, Productive Economy, Sociopreneurship, Street Children.

\begin{abstract}
ABSTRAK
Tujuan dari pelaksanaan pengabdian kepada masyarakat yang dilakukan untuk masyarakat khususnya para anak-anak jalanan yang berada di bawah naungan yayasan ERBE, Kebon Kopi Jakarta Timur adalah sebagai berikut: 1) Menurunkan jumlah anak-anak di bawah umur yang diberdayakan oleh orang tua sebagai sumber penghasilan. 2) Memperluas Peluang usaha yang relatif terbatas. 3) Menumbuhkembangkan pengetahuan yang diperoleh masyarakat mengenai kewirausahaan khususnya sociopreneurship yang baik dan benar, dan 4) mengoptimalkan usaha ekonomi produktif dan memperluas akses pasar bagi masyarakat yang telah memiliki usaha. Pelaksanaan kegiatan ini melibatkan 2 mitra (sasaran) masyarakat, yaitu Dinas Sosial Kota Jakarta Timur dan Yayasan ERBE, Kebon Kopi, Jakarta Timur. Kegiatan ini dilaksanakan pada 20 -21 November 2018. Kegiatan ini pada hari pertama dimulai pada pukul 09.00 - 12.00 WIB di Yayasan Anak Jalanan ERBE Kebon Kopi - Jakarta Timur dan hari kedua di Yayasan Anak Jalanan ERBE Kebon Kopi - Jakarta Timur pada pukul 14.00 - 17.00 WIB. Jumlah total peserta yang ikut adalah 50 orang. Hasil Pelaksanaan kegiatan Pengabdian Kepada Masyarakat ini
\end{abstract}


berupa subtema kegiatan " The Innovative Product Of Kain Perca" dan pengembangan karakter wirausaha melalui sociopreneur concept dapat dinilai sukses atau telah berhasil dilaksanakan dengan persentase perencanaan, hasilnya 91,66\%; 95\%, dan 87,5\% dalam kategori sangat baik.

Kata kunci: Anak Jalanan, Ekonomi Produktif, Sociopreneurship, Yayasab ERBE.

Ariwibowo, P., Priyono., \& Yulanda, N. (2019). Penerapan Social Preneurship dalam Pengembangan

Kualitas Potensi Hidup Anak Jalanan di Jakarta Timur. Jurnal Qardhul Hasan : Media Pengabdian kepada Masyarakat, 5(1), 7-14.

\section{PENDAHULUAN}

Di zaman millenial ini, tingkat kesenjangan sosial antara golongan masyarakat menengah ke atas dibandingkan dengan golongan masyarakat menengah ke bawah sudah semakin meruncing. Hal ini semakin terlihat jelas bahwa semakin rendahnya daya beli masyarakat khususnya bagi kalangan masyarakat menengah ke bawah. Kondisi tersebut mengakibatkan tingginya tingkat eksploitasi terhadap anak-anak, mulai dari usia 0 tahun hingga $<17$ tahun.

Ketidak merataan pendidikan yang dinikmati oleh masyarakat di Indonesia, mengakibatkan tingkat keahlian dan tingkat kesejahteraan masyarakat yang berdaya ekonomi menengah kebawah akan berkualitas lebih rendah dibandingkan masyarakat yang dapat mengonsumsi pendidikan hingga jenjang tertinggi.

Di tengah mirisnya kondisi tersebut, suka tidak suka kehidupan harus terus berjalan. Hal ini menunjukkan bahwa kebutuhan hidup tiap individu akan terus tercipta dan terpenuhi di tiap harinya. Dalam memenuhi kebutuhan hidup tesebut, tiap individu memiliki cara yang berbedabeda, bagi kalangan masyarakat menengah ke bawah akan menggunakan skill yang apa adanya baik yang berdasarkan pengalaman pribadi, pengalaman orang tua, maupun mengikuti pelatihan-pelatihan yang apa adanya.

Menurut (Anwar, 2004), life skill adalah pendidikan yang dapat memberikan bekal ketrampilan yang praktis terpakai, terkait dengan kebutuhan pasar kerja, peluang usaha dan potensi ekonomi atau industri yang ada di masyarakat. Broling (1989) dalam pedoman penyelenggaraan program kecakapan hidup pendidikan non formal mengelompokkan life skill menjadi tiga kelompok, yaitu: (1) Kecakapan hidup sehari-hari (daily living skill), antara lain meliputi: pengelolahan rumah pribadi, kesadaran kesehatan, kesadaran keamanan, pengelolahan makanan-gizi, pengelolahan pakaian, kesadaran pribadi warga negara, pengelolahan waktu luang, rekreasi, dan kesadaran lingkungan. (2) kecakapan hidup sosial/pribadi (personal) social skill), antara lain meliputi ; kesadaran diri (minat, bakat, sikap, kecakapan), percaya diri, komunikasi dengan orang lain, tenggang rasa dan kepedulian pada sesama, hubungan antar personal, pemahaman masalah, menemukan dan mengembangkan kebiasaan positif, kemandirian dan kepemimpinan. (3) kecakapan hidup bekerja (vocational skill), meliputi: kecakapan memilih pekerjaan, perencanaan kerja, persiapan keterampilan kerja, latihan keterampilan, pengusahaan kompetensi, menjalankan suatu profesi, kesadaran untuk menguasai berbagai keterampilan, kemampuan menguasai dan menerapkan teknologi, merancang dan melaksanakan proses pekerjaan, dan menghasilkan produk barang dan jasa.

Tenaga kerja merupakan penduduk yang berada dalam usia kerja. Menurut UU No. 13 tahun 2003 Bab I pasal 1 ayat 2 disebutkan bahwa tenaga kerja adalah setiap orang yang mampu melakukan pekerjaan guna menghasilkan barang dan atau jasa baik untuk memenuhi kebutuhan sendiri maupun untuk masyarakat. Secara garis besar penduduk suatu negara dibedakan menjadi dua kelompok, yaitu tenaga kerja dan bukan tenaga kerja.

Berdasarkan penduduknya, Tenaga kerja adalah seluruh jumlah penduduk yang dianggap dapat bekerja dan sanggup bekerja jika tidak ada permintaan kerja. Tenaga kerja diklasifikasikan menjadi 1) Menurut Undang-Undang Tenaga Kerja, mereka yang dikelompokkan sebagai tenaga kerja yaitu mereka yang berusia antara 15 tahun sampai dengan 64 tahun. 2) Bukan tenaga kerja. Bukan tenaga kerja adalah mereka yang dianggap tidak mampu dan tidak mau bekerja, meskipun ada permintaan bekerja. Menurut Undang-Undang Tenaga Kerja No. 13 Tahun 2003, mereka adalah penduduk di luar usia, yaitu mereka yang berusia di bawah 15 tahun dan berusia di atas 64 tahun. Contoh kelompok ini adalah para pensiunan, para lansia (lanjut usia) dan anak-anak. 
Anak-anak usia 0 - 15 tahun merupakan masa bagi individu untuk mengeksploitasi dan mengembangkan potensi diri dalam bentuk dunia bermain dan belajar, bukan dalam bentuk dunia kerja yang sebagai bahan eksploitasi bagi orang tua dalam meningkatkan kualitas perekonomian yang mengakibatkan tuntutan terhadap anak untuk melakukan berbagai aktivitas semakin meningkat. Tak terkecuali anak-anak putus sekolah, anak-anak yang tinggal di pinggiran ibukota maupun anak-anak yatim piatu juga mengalami hal yang sama.

Berdasarkan kualitasnya, tenaga kerja dibedakan menjadi : 1 . Tenaga kerja terdidik. Tenaga kerja terdidik adalah tenaga kerja yang memiliki suatu keahlian atau kemahiran dalam bidang tertentu dengan cara sekolah atau pendidikan formal dan nonformal. Contohnya: pengacara, dokter, guru, dan lain-lain. 2. Tenaga kerja terlatih. Tenaga kerja terlatih adalah tenaga kerja yang memiliki keahlian dalam bidang tertentu dengan melalui pengalaman kerja. Tenaga kerja terampil ini dibutuhkan latihan secara berulang-ulang sehingga mampu menguasai pekerjaan tersebut. Contohnya: apoteker, ahli bedah, mekanik, dan lain-lain.

Berdasarkan hal tersebut, mereka perlu dibekali dengan berbagai macam keterampilan untuk menghadapi tantangan masa depan. Salah satu keterampilan yang ingin difasilitasi oleh pengabdian masyarakat kali ini adalah mengenai socialpreneurship dengan judul kegiatan “ Penerapan Socialpreneurship Dalam Pengembangan Kualitas Potensi Hidup Pada Anak Jalanan di Jakarta Timur “.

Tabel 1. Jadwal Kegiatan

\begin{tabular}{|c|c|l|l|c|}
\hline WAKTU & NAMA KEGIATAN & \multicolumn{1}{c|}{ TEMPAT } & \multicolumn{1}{c|}{$\begin{array}{c}\text { RINCIAN } \\
\text { KEGIATAN }\end{array}$} & $\begin{array}{c}\text { PENANGGUNG } \\
\text { JAWAB }\end{array}$ \\
\hline \multicolumn{3}{|c|}{ Hari Pertama : Program Pengabdian Masyarakat (1) } \\
\hline $09.00-10.00$ & Persiapan Abdimas & $\begin{array}{l}\text { Briefing, } \\
\text { sarapan dan } \\
\text { persiapan } \\
\text { kegiatan yang } \\
\text { dilakukan oleh } \\
\text { Tim Abdimas }\end{array}$ & Pantor Kecamatan \\
& $\begin{array}{l}\text { Duren Sawit - } \\
\text { Jakarta Timur }\end{array}$ & Priyono \\
\hline
\end{tabular}

\section{MATERI DAN METODE}

Dalam rangka mencapai tujuan tercantum diatas, maka ditempuh langkah-langkah :

Menghubungi Ketua yayasan ERBE dan Ketua Yayasan ERKHA untuk mendiskusikan topik yang hendak diabdikan yaitu pemberdayaan usaha ekonomi produktif khususnya mengenai sociopreneur bagi masyarakat miskin dan mencari data jumlah warga masyarakat yang tergolong miskin khususnya anak-anak yang putus sekolah, yatim piatu dan diberdayakan untuk bekerja oleh orang tuasebagai calon peserta pelatihan.

Menyelenggarakan pelatihan, dengan materi: Pendidikan Karakter Pribadi; Kewirausahaan (Kewirausahaan Sosial/Sociopreneurship); Menemukan Peluang Usaha; Manajemen usaha; Peningkatan keterampilan, berupa pelatihan pembuatan produk yang disesuaikan dengan potensi warga masyarakat seperti kuliner, kerajinan tangan, dan keahlian lainnya.

Untuk menilai keberhasilan program kegiatan ini adalah : 80\% peserta yang diundang hadir dalam pelatihan; Terlaksananya seluruh kegiatan pelatihan kewirausahaan; $40 \%$ peserta mampu mengembangkan usaha ekonomi produktif dengan pendampingan dari tim pengabdi berupa peserta apat menghasilkan produk bernilai ekonomis sebagai sumber penghasilan sehingga peserta abdimas (anak-anak jalanan) tidak kembali "mengais rejeki" di jalanan kembali di masa mendatang; Pernyataan kepuasan dari peserta pelatihan, dan pemerintah setempat.

Pernyataan kepuasan dari peserta pelatihan, dan pemerintah setempat. Bentuk kegiatan pengabdian kepada masyarakat berjudul : "Penerapan Socialpreneurship Dalam Pengembangan Kualitas Potensi Hidup Pada Anak Jalanan di Jakarta Timur" ini akan dilaksanakan dengan rincian ; 


\begin{tabular}{|c|c|c|c|c|}
\hline $10.00-11.00$ & $\begin{array}{l}\text { Pelatihan Pendidikan } \\
\text { Karakter Anak Usia } 5 \\
\text { s/d } 21 \text { Tahun }\end{array}$ & $\begin{array}{l}\text { Kantor Kecamatan } \\
\text { Duren Sawit - } \\
\text { Jakarta Timur }\end{array}$ & $\begin{array}{l}\text { Seluruh Peserta } \\
\text { dan Panitia } \\
\text { mengikuti } \\
\text { kegiatan } \\
\text { Abdimas } \\
\text { (Pemateri : } \\
\text { Priyono) }\end{array}$ & \\
\hline $11.00-12.00$ & $\begin{array}{l}\text { Pelatihan } \\
\text { "Socialpreneurship } \\
\text { Dalam Pengembangan } \\
\text { Kualitas Potensi Hidup } \\
\text { Pada Anak Jalanan" }\end{array}$ & $\begin{array}{l}\text { Kantor Kecamatan } \\
\text { Duren Sawit - } \\
\text { Jakarta Timur }\end{array}$ & $\begin{array}{l}\text { Seluruh Peserta } \\
\text { dan Panitia } \\
\text { mengikuti } \\
\text { kegiatan } \\
\text { Abdimas } \\
\text { (Pemateri : } \\
\text { Prasetio } \\
\text { Ariwibowo) }\end{array}$ & \\
\hline $12.00-13.00$ & $\begin{array}{l}\text { Ramah Tamah dengan } \\
\text { Disnaker, Pengurus } \\
\text { Yayasan dan } \\
\text { perangkatnya }\end{array}$ & $\begin{array}{l}\text { Kantor Kecamatan } \\
\text { Duren Sawit - } \\
\text { Jakarta Timur }\end{array}$ & $\begin{array}{l}\text { Ishoma dan } \\
\text { Pengembangan } \\
\text { kegiatan untuk } \\
\text { pengelolaan } \\
\text { dan } \\
\text { pengembangan } \\
\text { kualitas hidup } \\
\text { anak jalanan di } \\
\text { masa } \\
\text { mendatang }\end{array}$ & \\
\hline \multicolumn{5}{|c|}{ Hari Kedua : Program Pengabdian Masyarakat (2) } \\
\hline 08.00-09.00 & $\begin{array}{l}\text { Briefing, sarapan dan } \\
\text { persiapan kegiatan }\end{array}$ & $\begin{array}{l}\text { Kantor Kecamatan } \\
\text { Duren Sawit - } \\
\text { Jakarta Timur }\end{array}$ & TIM & \multirow{3}{*}{$\begin{array}{c}\text { Prasetio, Rudeva, } \\
\text { dan Novidya Yulanda }\end{array}$} \\
\hline $09.30-12.30$ & $\begin{array}{l}\text { Workshop “ } \\
\text { Peningkatan kualitas } \\
\text { dan nilai ekonomis } \\
\text { pribadi melalui nilai } \\
\text { tambah Industri kreatif } \\
\text { barang-barang bekas } \\
\text { dan pantas pakai “ }\end{array}$ & $\begin{array}{l}\text { Kantor Kecamatan } \\
\text { Duren Sawit - } \\
\text { Jakarta Timur }\end{array}$ & $\begin{array}{l}\text { Seluruh Panita } \\
\text { (Pemateri : } \\
\text { Rudeva, dan } \\
\text { Novidya } \\
\text { Yulanda) }\end{array}$ & \\
\hline $12.30-13.30$ & Ishoma & $\begin{array}{l}\text { Kantor Kecamatan } \\
\text { Duren Sawit - } \\
\text { Jakarta Timur }\end{array}$ & & \\
\hline
\end{tabular}

Materi yang disampaikan kepada anak-anak jalanan, putus sekolah, dan anak yatim piatu di Jakarta Timur adalah membantu program pemerintah khususnya program dari Dinas Tenaga Kerja Jakarta Timur dalam mengurangi jumlah eksploitasi anak di jalanan di masa mendatang yang dikemas dalam bentuk pendidikan karakter diri, pengetahuan mengenai entrepreneurship yang mendukung kondisi para peserta abdimas di masa kini hingga masa mendatang berupa sociopreneurship, serta pelatihan mengenai pengelolaan dan bagaimana memanfaatkan barang-barang bekas dan pantas pakai agar memiliki nilai ekonomi. Secara garis besar ringkasan materi yang akan diberikan meliputi:

Pelatihan Pengenalan Karakter, Pendidikan Karakter dan Berbagai Jenisnya. Materi ini meliputi pengenalan dasar-dasar karakter, pendidikan karakter dan berbagai macam jenisnya. Pemberian pelatihan ini akan memberikan dasar pengetahuan dan keterampilan bagi anak-anak jalanan untuk dapat menjadi insan yang selalu positif dan sumber inspirasi yang memiliki nilai positif dan nilai ekonomis yang lebih baik bagi dirinya pribadi dan lingkungannya di masa mendatang.

Pelatihan Socialpreneurship materi pelatihan ini berkenaan dengan pelatihan untuk memberikan pengetahuan mengenai tata kelola/manajemen usaha (Manajemen Produksi, Pemasaran, Keuangan, dll.) baik perusahaan startup maupun yang telah berjalan, memberikan pengetahuan bahwa dalam memulai dan menjalankan usaha tidak selalu bermindset "Money Oriented" namun dalam berwirausaha mampu menyelesaikan Mass Conflict dan pendapatan akan diperoleh berdasarkan benefit 
yang dirasakan oleh masayarakat sekitarnya. Contoh: Permasalahan utama di suatu lingkungan adalah Tawuran dan Kriminalitas di usia dini, maka bentuk usaha yang dilakukan adalah membentuk yayasan atau lembaga yang melindungi dan mendidik anak usia dini $(0-18$ tahun).

Workshop Hasil Olahan (Industri kreatif) barang-barang bekas dan pantas pakai. Workshop " Peningkatan kualitas dan nilai ekonomis pribadi melalui nilai tambah Industri kreatif barangbarang bekas dan pantas pakai " berkenaan dengan Usaha ini berguna dalam penciptaan produk yang nantinya hanya akan di gunakan bagi peserta abdimas. Juga berupaya menambah kreatifitas dan mengeluarkan ide-ide kreatif. Salah satu bentuk kegiatan yang akan diadakan yaitu Kerajinan Aneka Kreasi Kain Flannel. Alasan dalam memilih Usaha Aneka Kreasi Kain Flanel, berdasarkan atas pertimbangan-pertimbangan sebagai berikut : Kain flannel memiliki banyak warna sehingga perpaduan warna dari kain flannel menghasilkan sesuatu yang sangat menarik, selain itu kain flannel Juga mudah dibentuk sehingga hasil kreasi dari kain flannel diminati oleh sebagian besar orang disemua kalangan usia; Kain flannel merupakan bahan yang murah. Namun, kreasi yang dihasilkan memiliki nilai jual yang cukup tinggi tergantung dari tingkat kerumitan dan kreativitas pembuat; Pemateri memiliki pengalaman dalam mendesain yang pernah kami dapatkan dari berbagai sumber baik mempraktikkan sendiri melalui kegiatan abdimas di tempat lain, buku maupun via internet. Bahkan salah satu pemateri telah memiliki usaha sendiri yang cukup berkembang yang bergerak di industri kreatif kain flanel.

\section{HASIL DAN PEMBAHASAN}

Tingkat keberhasilan layanan masyarakat terletak pada praktik berbagai teori yang telah diberikan tentang kewirausahaan oleh instruktur dalam bentuk lokakarya yang telah dihasilkan oleh peserta abdimas dilakukan melalui pengamatan langsung oleh instruktur melalui penilaian kinerja dan hasil produk kepada peserta di persiapan, pelaksanaan dan proses evaluasi dalam pembuatan produk fungsional dari bahan kaca kaca dengan mengacu pada indikator yang ditetapkan oleh instruktur. Model indikator penilaian yang digunakan untuk menilai keterampilan proses adalah sebagai berikut:

Tabel 2. Nilai Skala Tabel Pengolahan Produksi Fungsional.

\begin{tabular}{|c|c|c|}
\hline \multirow[t]{2}{*}{ No. } & \multirow[b]{2}{*}{$\begin{array}{c}\text { Kriteria Keterampilan } \\
\text { Yang Diamati }\end{array}$} & Skala Nilai \\
\hline & & $\begin{array}{llll}4 & 3 & 2 & 1 \\
\end{array}$ \\
\hline 1 & $\begin{array}{lr}\text { Persiapan } & \text { untuk } \\
\text { (Pemilihan } & \text { material, } \\
\text { pengukuran, } & \text { dan } \\
\text { penyetelan Alat) } & \end{array}$ & \\
\hline 2 & $\begin{array}{l}\text { Penggunaan Peralatan } \\
\text { yang benar }\end{array}$ & \\
\hline 3 & $\begin{array}{l}\text { Akurasi } \\
\text { Langkah mak e penciptaan } \\
\text { produk fungsional }\end{array}$ & \\
\hline 4 & $\begin{array}{l}\text { The Kesesuaian hasil } \\
\text { akhir yang disajikan } \\
\text { sesuai dengan kriteria } \\
\text { yang telah diterapkan }\end{array}$ & \\
\hline 5 & $\begin{array}{l}\text { Mengatur peralatan } \\
\text { setelah selesainya } \\
\text { aktivitas }\end{array}$ & \\
\hline 6 & Produk Kreativitas & \\
\hline 7 & Kerapian produk & \\
\hline 8 & Kombinasi warna & \\
\hline & $\begin{array}{l}4=\text { Sangat Baik, } 3 \text { = Bagus } \\
\text { Kurang }\end{array}$ & Cukup, $1=$ \\
\hline
\end{tabular}

Selanjutnya hasil akhir penilaian kinerja dirata-ratakan dan dikonversi menggunakan pedoman konversi berikut:

Tabel 3. Evaluasi Pedoman Hasil.

\begin{tabular}{cccc}
\hline No. & Additonal & Skor & Kategori \\
\hline 1 & $85-100$ & 4 & $\begin{array}{c}\text { Sangat } \\
\text { bagus }\end{array}$ \\
2 & $70-84$ & 3 & Baik \\
3 & $55-69$ & 2 & Cukup \\
\hline 4 & $<54$ & 1 & Kurang \\
\hline Kegiatan & \multicolumn{2}{c}{ workshop } & "Penerapan
\end{tabular}

SocialPreneurship Dalam Pengembangan Kualitas Potensi Hidup Pada Anak Jalanan di Jakarta Timur" di Yayasan Anak Jalanan ERBE Kebon Kopi - Jakarta Timur yang diadakan pada 20 -21 
November 2018. Kegiatan ini pada hari pertama dimulai pada pukul 09.00 - 12.00 WIB di Yayasan Anak Jalanan ERBE Kebon Kopi - Jakarta Timur dan hari kedua di Yayasan Anak Jalanan ERBE Kebon Kopi - Jakarta Timur pada pukul 14.00 17.00 WIB. Pada hari pertama, Kegiatan ini dimulai dengan mengumpulkan peserta di aula multiguna Yayasan Anak Jalanan ERBE sebagai tempat pelatihan. Ditargetkan jumlah peserta yang 100 orang yang merupakan seluruh anggota (anak asuh/peserta didik) Yayasan ERBE. Tetapi pada pelaksanaannya baik pada saat hari pertama maupun pada saat hari kedua, pihak ERBE hanya mampu mengumpulkan 50 anak yang mengikuti pelatihan / workshop.

Gambar 1. Pelatihan Pengenalan Karakter Pendidikan Karakter dan berbagai Jenisnya.

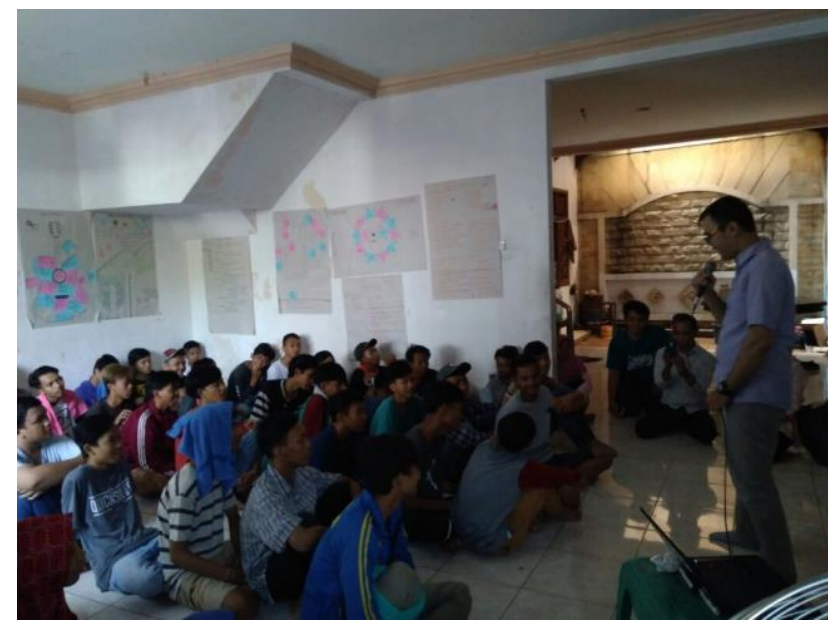

Pada hari pertama, instruktur (Priyono) membahas masalah yang berkaitan dengan pembentukan karakter dan penggalian potensi diri yang baik dan sejati melalui metode ceramah dan diskusi.Peserta sangat antusias mengikuti kegiatan ini, dan sangat tertarik untuk memahami kekurangan dan kelebihan yang mereka miliki serta mengembangkan kelebihan potensi diri yang belum atau sudah diketahui oleh peserta dengan baik dan benar.

Acara Kedua, instruktur (Prasetio Ariwibowo) menyampaikan tentang Konsep Manajemen Bisnis Terpadu dan SocioPreneurship melalui metode ceramah dan diskusi. Peserta sangat antusias dalam mengikuti kegiatan ini, pola pikir dan pengetahuan peserta menjadi lebih terbuka dan memahami untuk memahami tentang kondisi ekonomi, filosofi, dan teknik / konsep / sistem manajemen bisnis terpadu dalam menghadapi kondisi ekonomi yang fluktuatif dengan cara yang baik dan benar khususnya dapat mengetahui apa dan bagaimana sebenarnya makna dan pelaksanaan bisnis sociopreneur tersebut.
Sosialisasi program perencanaan

Gambar2. Workshop Hasil Olahan (Industri Kreatif) barang-barang bekats dan pantas pakai.

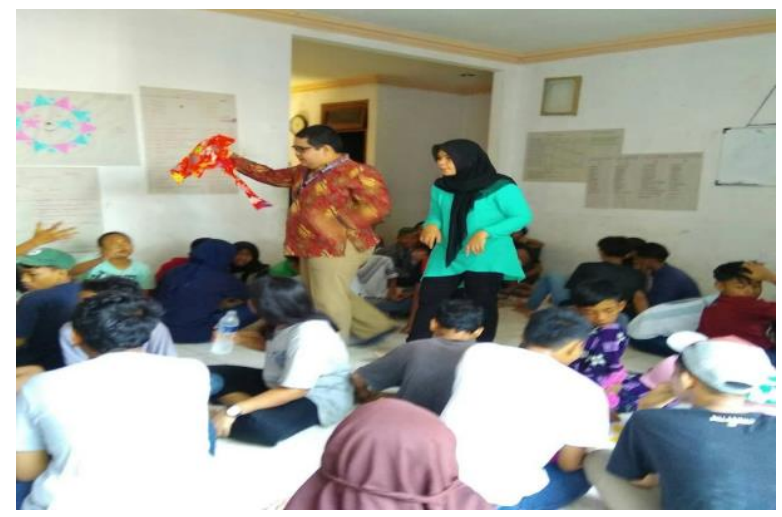

Acara Selanjutnya, Instruktur (Novidya Yulanda) dibantu oleh Prasetio dan Rudeva, salurkan hal-hal yang melibatkan dengan membuat output berupa kreasi benda fungsional melalui metode ceramah, diskusi, dan workshop yang menghasilkan produkproduk kreativitas yang memiliki nilai jual. Para peserta sangat antusias mengikuti kegiatan ini, dan mereka sangat tertarik untuk berlatih dari teori yang mereka peroleh.Setiap peserta dibebaskan untuk membuat kreasi fungsional dari barangbarang tidak terpakai seperti barang-barang yang terbuat dari kain perca, ban/karet bekas dan botol plastik air mineral menjadi suatu produk kreatif dan bernilai ekonomis baik meniru contoh-contoh yang telah disiapkan atau membuat kreasi mereka sendiri. Setiap peserta yang telah menyelesaikan produknya diberi kesempatan untuk membuat pola yang berbeda sesuai dengan yang diinginkan setiap peserta.

Hasil lokakarya tentang penciptaan bendabenda fungsional dari barang-barang yang sudah tidak terpakai tersebut yang terbuat dari botol air mineral dan kain perca secara umum dapat dikatakan berhasil. Hal ini dapat dilihat dari persentase kehadiran yang mencapai kisaran $100 \%$ dari total 50 peserta yang diharapkan. Dari para peserta ada dibagi menjadi 10 kelompok yang terdiri dari 5 orang per kelompok. Berdasarkan perencanaan, proses, dan hasil latihan dapat digambarkan sebagai berikut: 
Tabel 4 Rekapitulasi Hasil Pembuatan Data Aktivitas "The Innovative Product Of Kain Perca" Di Yayasan ERBE Anak Jalanan Jakarta Timur .

\begin{tabular}{ccccc}
\hline $\begin{array}{c}\text { No. } \\
\text { Kelompok }\end{array}$ & Plaining & Process & Result & Total \\
\hline 1 & & & & \\
2 & 4 & 4 & 4 & 12 \\
3 & 3 & 4 & 4 & 11 \\
4 & 4 & 3 & 4 & 12 \\
5 & 4 & 4 & 4 & 12 \\
6 & 4 & 4 & 3 & 10 \\
7 & 3 & 4 & 3 & 11 \\
8 & 3 & 4 & 3 & 10 \\
9 & 4 & 3 & 3 & \\
10 & 4 & 4 & 35 & $91,66 \%$ \\
\hline dari Total & 4 & 38 & $87,5 \%$ & \\
\hline$\%$ & $92,5 \%$ & $95 \%$ & & \\
\hline
\end{tabular}

Berdasarkan Tabel dapat kita ketahui bahwa dalam perencanaan pembuatan kerajinan tangan kain perca dan botol air mineral fungsional ini menjadi " The Innovative Product Of Kain Perca " mendapatkan nilai $91,66 \%$ dalam kategori sangat baik, proses pembuatan barang fungsional ini mendapat 95\% yang artinya sangat baik dan dalam tahap hasil mendapatkan nilai yang sama yaitu sebesar 87,5\% yang berarti dalam kategori sangat baik. Dari ketiga hasil tersebut, dapat disimpulkan bahwa nilai kerajinan dari kerajinan tangan yang dihasilkan oleh peserta abdimas melalui semangat mental kewirausahaan pada anak Jalanan Yayasan ERBE Jakarta Timur dikelola sesuai dengan harapan.

Berdasarkan hasil Kegiatan Pengabdian Masyarakat (Abdimas) yang telah disajikan dalam hasil, kegiatan ini mendapat respon yang sangat positif dari para peserta, ketua yayasan, Pihak manajemen, dan kakak pendamping dari para anak-anak jalanan yang menjadi anggota yayasan anak jalanan ERBE Kebon Kopi - Jakarta Timur. Para peserta sangat antusias mengikuti kegiatan ini dan hasilnya sangat bagus, serta pihak manajemen dan kakak pemdamping yang dengan senang hati memfasilitasi kelancaran kegiatan kegiatan pengabdian masyarakat ini.

Gambar 3. Aktivitas Workshop Hasil Olahan (Industri kreatif) Kain Flanel Dari Peserta Abdimas.

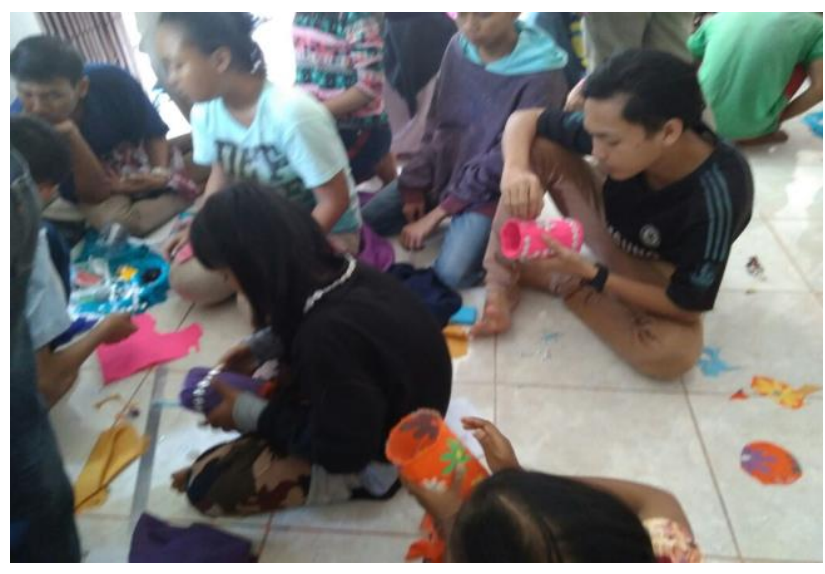

Ada beberapa kendala dalam pelaksanaan abdimas ini dalam hal kedisplinan, peralatan dan perlengkapan bantu Abdimas yang terbatas, serta ruangan yang kurang memadai dalam menyalurkan aspirasi dari para peserta abdimas. Hal ini dikarenakan habbit peserta abdimas yang terbiasa dengan kehidupan tanpa keterikatan secara lahir maupun batin, tim abdimas hanya menyediakan perlengkapan abdimas (lem "tembak" korea, gunting, lempengan motif, pernak pernik hiasan, dll. Namun keterbatasan tersebut dapat teratasi dengan pihak manajemen Yayasan ERBE menyediakan berbagai kekurangan peralatan tersebut dan membantu dalam mendidik para peserta (anak jalanan) menjadi lebih tertib dan disiplin sehingga kegiatan pengabdian masyarakat dapat berjalan dengan tertib dan lancar. 
Kreasi " The Innovative Product Of Kain Perca " para peserta dibuat sesuai dengan harapan, instruktur menargetkan bahwa para peserta dapat membuat kerajinan tangan sesuai dengan kriteria yang ditetapkan oleh instruktur dalam hal ukuran, warna, desain gambar, jiwa dan pola pikir kewirausahaan baik dan benar, manajemen kewirausahaan yang baik benar dari awal hingga akhir produksi dan kriteria lainnya.

Namun demikian, kerja sama yang sangat aktif dari para peserta untuk menyelesaikan setiap tugas, dapat dilakukan oleh para peserta dengan tanggung jawab penuh dan dapat tertanam dalam pikiran dan semangat semangat masing-masing peserta tentang apa yang harus mereka lakukan setelah mereka menyelesaikan sekolah mereka di masing-masing mereka.setiap sekolah adalah mayoritas yang ingin menjadi seseorang yang menghasilkan dan berguna bagi orang lain adalah menjadi wirausaha yang baik dan benar daripada melanjutkan pendidikan ke universitas. Ini menyiratkan bahwa mereka sangat disiplin dengan waktu meskipun mereka memiliki kurangnya pemahaman dan tingkat kecerdasan yang telah diremehkan oleh publik tetapi mereka memiliki semangat besar untuk belajar menjadi orang yang lebih baik di masa depan.

\section{KESIMPULAN DAN IMPLIKASI}

Berdasarkan hasil dan pembahasan kegiatan pengabdian masyarakat yang telah dijelaskan sebelumnya, dapat ditarik kesimpulan sebagai berikut:

Pelaksanaan kegiatan Pengabdian Kepada Masyarakat di Yayasan Anak Jalanan ERBE Kebon Kopi - Jakarta Timur yang diadakan pada 21 - 22 November 2018 dalam bentuk " The Innovative Product Of Kain Perca " dan pengembangan karakter wirausaha melalui sociopreneur concept dapat dinilai sukses atau telah berhasil dilaksanakan dengan persentase perencanaan, hasilnya 91,66\%; 95\%, dan 87,5\% dalam kategori sangat baik.

Kegiatan Pengabdian Kepada Masyarakat di Yayasan Anak Jalanan ERBE Kebon Kopi - Jakarta Timur yang diadakan pada 21 - 22 November 2018 dalam bentuk " The Innovative Product of Kain Perca " dan pengembangan karakter wirausaha melalui sociopreneur concept sangat baik. Ini terbukti dari indikator kehadiran peserta yang mencapai $100 \%$ dari jumlah peserta yang menargetkan kehadirannya. Selama acara tersebut berlangsung, para peserta sangat antusias mengikuti kegiatan dari awal sampai akhir kegiatan untuk mengetahui tips untuk menjadi pengusaha yang baik terutama menjadi pengusaha yang tanpa mengeluarkan modal namun memperoleh pendapatan bahkan dapat menjadi solusi bagi lingkungan sekitar minimal di lingkungan sekitar tempat tinggalnya di masa yang akan datang.

\section{DAFTAR PUSTAKA}

Anggraini, Nenny, 2008. Industri Kreatif, Jurnal ekonomi Desember 2008 Volume XIII No. 3 hal. 144-151.

Anwar. 2004. Pendidikan Kecakapan Hidup : (Life Skills Education). Bandung : Alfabeta.

Atmosudiro, Sumijati. 2001. Jawa Tengah: Sebuah Potret Warisan Budaya, Suaka. Peninggalan Sejarah dan Purbakala Propinsi Jawa Tengah di Prambanan.

Brolin, D.E. (1989). Life Centered Career Education : A Competency. Based Aprroach Reston VA; The Council for Exceptional Chidlren.

Kementerian Ketenagakerjaan. (2003). UndangUndang Nomor 13 Tahun 2003 tentang Ketenagakerjaan (Lembaran Negara Republik Indonesia Tahun 2003 Nomor 39, Tambahan Lembaran Negara Republik Indonesia Nomor 4279). Jakarta. 